\title{
Dialogue Between Teacher and Learners in English Class: The Case of Adult Learning Activities
}

\section{lian Purnama}

\section{Lecturer of STAIN Purwokerto}

Kstrak: Pengajaran bahasa Inggris untuk orang dewasa memeriukan pendekatan khusus =-s kondisi orang dewasa yang unik dengan berbagai persoalan baik psikologis maupun aja tangkapnya. Di samping itu, kemampuan pembelajaran mandiri juga mungkin - bangkan sebagai alternatif untuk mencapai hasil pembelajaran yang maksimaL. Untuk Z Sbutuhkan suatujembatan pemahaman, atau dialog antara pengajar dengan pembelajar. $\underline{a}=$ proses pembelajaran tetapi merupakan aspek kegiaatan yang harus didesain sebagai fan integral dari strategi pembelajaran bahasa bagi orang dewasa.

Kata kunci: Dialogue, adult learners, Management of interraction, Joint process.

\section{introduction}

Teaching language can work well if there is sufficient knowledge of the groperties and behavior of learners. Successful or unsuccessful learners, caused - various factors; one of them is the quality of relationships between people sho learn with teachers or lecturers. As quoted by Sugeng, et al, stated, "All ficms of language teaching can be developed properly if we have enough tnowledge about learners and about learning and teaching process itself." Thus, knowledge about the learning process will assist in facilitating the learning and teaching so that learners can achieve maximum results.

This paper is one attempt to find the necessary activities in the learning process in a class of adults who learn the language. By specializing on the adult fearner, this paper is intended to identify things that are needed by teachers or lecturers and adult learners in the learning process of English as a foreign language. This paper is expected, among others, could contribute to growth and development of theories about the activities in the classroom in teaching English as a foreign language to adult learners. 
Discussions of teaching, learning, and assessment in the context of Indonesia at the present time have to recognize that these are controversial and contested topics. Within the broad context of education as a whole, the increasing political attention paid to what teachers actually do in classrooms, as well as the charged debates about the increasingly selective processes by which learners in schools transfer between primary and secondary schooling, secondary and tertiary phases, and between tertiary and university or the world of work, have brought ideas about assessment onto the centre stage of political and media discussion. For adult learners, these conditions are in some ways even more pointed because the system is still dominated by and organized around the idea of education as something mainly for children and young people, undertaken full-time, and leading in an uncomplicated way to national qualifications. The range of purposes for learning and the meanings of success and achievement in learning are more complex and diverse in relation to adult leamers. Rather, adult learners have to fit into a system ever more narrowly-focused on the goal of improving industrial and business productivity, and which utilizes indicators of achievement, success and quality designed for that purpose alone.

It is quite important of ensuring that there is an appropriate "atmosphere" in the class for effective learning. The atmosphere must meet the need to enable adult learners, particularly those new to formal learning, or who have had negative previous experiences of education, to be relaxed and comfortable, so that they are ready for effective learning, and to face any challenges involved.

For adult educators, this has always been one of the first rules for teachers, based on the assumption that for many adults, formal learning may be an unfamiliar and potentially threatening experience. The elements that contribute to the "atmosphere" of the class include the physical environment, the layout of the room, the behavior of other students, and, most importantly, the behavior of the teacher. Teachers are encouraged to work on generating friendly relations, goodwill and trust between all the members of the group, so that individual students are more willing to take risks, to expose themselves, as part of the sometimes difficult process of learning.

Learning through dialogue is a major theme in the literature on adult learning, though it appears with a wide variety of nuances and emphases. For Knowles 
55t dialogue is both practical and political. Firtsly, it recognizes the centrality Ftestus of the learners as adults and enables the exposition and utilization their accumulated experience and knowledge for the benefit of everyone in Foup. Secondly, it is through dialogue with the learners themselves that the eacher can best discover how to differentiate (or perhaps "personalize") the aning program so that the diversity of needs and purposes among any group therners can be addressed. Thirdly, dialogue enables teachers to orient the - ing program towards those particular tasks. ${ }^{2}$

Aditically, Hostler (1986) agrees that if we see adults as autonomous and flirecting, they have a right to participate in decisions that affect them ${ }^{3}$. it relation to learning; participation cannot be achieved without discussion ad dialogue between all the members of the group. A vision of groups as models for democratic practice through discussion and debate is one of the ingest-established elements of a major, influential tradition in British adult eftucation, originating in the corresponding societies and 19 th century socialist novements. ${ }^{4}$

Yet, a utilitarian shift is evident in recent writing, where similar modes and epoused values of learning and participation are recommended for effectiveness ather than democratic propriety. The earlier focus on democratic discussion and debate was content-focused, aiming to share experiences and accumulated knowledge of the topic in hand. In contrast, a recent focus is on discussion of learning itself, and of the ways in which it can be evaluated and developed. This emphasis is seen nor just as a means of improving attainment but, variously, as capacity-building for the future, as a means of addressing anxiecy or lack of motivation about learning 7 , and/or as a way of building autonomy. ${ }^{8}$

In other words the earlier focus of this tradition was concerned with a democratic process of deciding the 'what' of a particular course of adult learning and maximizing the resources of knowledge and experience available to the group: more recent studies are more concerned with promoting learner participation in order to make any learning process more effective, in terms both of accountability to taxpayers and to individual learners themselves. This practical perspective is supported also by Tusting and Barton (2003), whose survey of models and theories of adult learning concludes with seven key ideas 
about how adults learn: that adults have their own motivations for learning: based on their existing knowledge and experience, that adults have a drive towards self-direction and autonomy, that adults can learn about their own learning processes, that all real life activities contribute to adult learning, that adults reflect and build on their experience, that reflective learning is unique to each person and often incidental and idiomatic, and finally that learning can be transformative, enabling people to reorganize their experience and see situations in new ways?

The writers reviewed in this section fall into two categories: those who treat dialogue as central to all teaching and learning, and those who write about particular pedagogical objectives that can be achieved through using dialogue. The first group treats dialogue between learners as well as between learners and teachers, as of central importance; the second group focus more on the role of dialogue between teacher and learner. We discuss each group in turn in the following subsections.

\section{Dialogue as the Central of Teaching and Learning Process}

Vygotsky, as quoted by Alexander, claims that learning is a social process where the true direction of learning is not from the individual to the social, but from the social to the individual. ${ }^{10}$ For him, teachers are not merely facilitators, secondary to the process as theories of andragogy would have it, nor mere transmitters of learning. Instead, learning is a process with teachers and learners as interactive participants: both learner engagement and teacher interventions are essential. Nevertheless, Alexander believes that what learners say is more important than what teacher say, implying that dialogue enables teachers to facilitate future planning of the learning process on the basis of their interpretation of what learners say. As Alexander's focus is primarily on the education of children, this is an argument for dialogue based on its efficacy for school learning rather than its political desirability; however, he also points out that if it is effective for children's learning, then it will also be for adult education, including the education of teachers. Alexander characterizes dialogic teaching as collective, reciprocal, supportive, cumulative, and purposeful, viewing knowledge as problematic and open rather than given and closed. ${ }^{11}$ In a similar vein, 
Girr argues that: "A sacio-cultural educational perspective sees learning as induction Is 'discourses' or 'communities of practice' througb interaction witb more expert atbers. Ar she beart of any disonurse is the language and symbols that carry its special meanings. I become a member of the discourse one must begin to learn its language."

In relation to numeracy teaching, Marr argues that students need opporunities to learn the language of mathematics through talking and dialogue in onder to support subject learning, as well as to improve their capacity for leiming, autonomy or motivation. She argues that learning activities that provide access to and practice in subject discourse are more pressing in mathematics than other subjects, because of the relarive absence of explanatory =ritten texts available to students.

Whereas most other subject areas rely on an extensive canon of write prose (to be found in textbooks, encyclopedias and school libraries) to provide the impression of stability and permanence to knowledge, this is noticeably absent in mathematics. Textbooks tend to be pastiches of repetitive activities and fragments of knowledge. . $^{3}$

This produces a heavy reliance on the teacher's verbal explanations to carry the knowledge and understanding of the subject. Reliance on the spoken mode begins to explain the "catechistic" type of interaction so prevalent in mathematics classrooms. ${ }^{\text {It }}$ If transmission dominates mathematics in order to define and control the curriculum, it is not surprising that interactive, open-ended and investigative dialogic activities are relatively uncommon.

Very similar perspectives are taken by Swan introducing a collection of resources aiming to support teachers of mathematics in post- 16 education to develop their practice. Swan also sees the main task as to move from 'transmission' to 'connective and challenging' modes of teaching, and from 'passive' to 'active' modes of learning. He doesn't see dialogue as a simple two-way process between equals: for him the teacher has a critical pro-active and leadership role, demanding complex and high level skills. If the dialogue is to be purposeful, the teacher needs to make its purpose clear, encourage an exploratory and reflective mode of discussion, encourage 'discussion of alternative methods and understandings', welcome mistakes and misconceptions as opportunities for learning, ask probing, challenging questions of learners, and finally, to draw out the important ideas arising from each session. ${ }^{15}$ 
Absolum's work is based on long-term development work in 10 New Zealand schools. It is included in this review because his is a fully worked-out guide to the use of formative assessment approaches in teaching and learning that appears to be applicable to any sector. ${ }^{16}$ While he doesn't refer explicitly to lifelong learning, he bases his work on learning theorists such as Argyris and Schon (1974) and Sadler (1989), whose theories focus on learning in general, rather than in any specific context or phase of life. ${ }^{17}$

That his book is relevant to a consideration of adult learning is also suggested by the fact that his discussion is explicitly applied to the teaching and learning of all age groups within schools, more or less without distinction. He argues that to be effective, learning must enable the learner to own the learning process, and to be significant, it must result in the learner owning what is learnt. His ideas link the work of Black and Wiliam with the work of Argyris and Schön (1974) on organizational learning. At the centre of what he sees as an 'archway of teaching and learning capabilities' he puts the development of 'learningfocused relationships' between teacher and learners, and between learners themselves: the key mechanism for this is continuous, interactive dialogue. ${ }^{18}$

Many other reports also highlight the significance of learners' feelings about learning, and of the relationships between teachers, learners, and others: relationships matter in learning, including teacher-student and student-student relationships, also networks of support learners are part of it'. 'Feelings and emotions shaped people's experiences of learning. For some this made engagement, particularly in more formal, structured learning very difficult while other people calked about formal learning provision as a safe haven from orher overwhelming issues in their lives. ${ }^{20}$ Teachers must be able and willing to engage with the complexity of learners' different and developing states of mind and feeling about learning, because there is a complex relationship between teaching and learning: learners don't learn what teachers teach', ${ }^{21}$

This point is made in different ways by a number of commentators. Barton and Papen ${ }^{27}$ argue that for effective learning to take place, teachers must be willing to engage with wider aspects of people's lives. Nonesuch ${ }^{33}$ points out that whether you are a therapist or not, the emotions in your math class are not going away. She sees this issue as a key part of pedagogy. For her, students' 
ings about learning must be made explicit if they are not potentially to be rrier, and this is another way in which the teacher needs communicative s of the highest order. Her work draws strongly on that of Ginsburg and who propose 13 principles for effective adult numeracy teaching, many which depend on the facilitation of dialogue in the classroom, including the to address students' attitudes and beliefs regarding learning and tsematics, to determine what students already know, to encourage the trice of estimating skills, and group activities such as searching for multiple stions to the same problems, etc. Most of these strategies are also evaluated Explored in great derail by Swan. ${ }^{25}$

Franic and Tseng (2005) also take a radical view of the importance of dialogue udult learning: 'Learning is not predictable as a product of inpur, but created ugh constant negotiations between individuals, social environments and sder social influences'. They suggest that teachers need to pay attention to beliefs about learning, teaching, language literacy and numeracy that mers and teachers bring with them to the learning-teaching encounter, and teachers should identify learners' intentions as a key factor in learning tnts. 'Social interaction is the key mechanism through which learning takes lice. Teaching is best characterized as the creation of 'learning opportunities' trough the management of interaction ${ }^{26}$ Belzer suggests that adult literacy amers' constructions of previous learning contexts can function as 'screens' erween the learner and effective learning. Contextual features of current aming contexts may pass easily through a learner's screen, may be a misfit rating ambivalence and tension, or may exceed the boundary of the screen's ame. This perspective, like the ones referred to above, proves problematic to te notion of the simple transmission of learning in these contexts, and can ity be addressed by rich communicative interaction between learners and machers. ${ }^{2}$ Baxter, et al., record students discussing the greater confidence $\Rightarrow$ felt as a result of being known individually by the teacher, in sharp contrast school and some previous adult experiences. They valued both individual clarionships with their teachers and also group working, which allowed for ipportive relationships to develop between the students themselves. ${ }^{28}$ 
An influential figure is Freire (1972), who criticizes what he calls the ban: system' of education in which teachers deposit knowledge into passive learn based on a static, positivist view of For him, liberating education overcome. Dialogue portrays reality as a prox entity. ${ }^{29}$

From this perspective, teaching based on dialogue is ongoing format assessment, where reflection and negotiacion between all participants focu on what is learned and how successfiul the pry neither a gift nor an imposition of bits of in but rather an organized, systematized and developed that people want to know more about.

Teachers engage in dialogue in order to understand learners 'objective situation and to develop learners' awareness of that situation. Teachers must develop materials and activities that enable fearners to pose problems, to facilitate dialogue aimed at understan solutions. Teachers therefore need to establish a learning context in which theit
authority is not oppressive, so that learning takes place on the learner' own
territory, using dialogue and content led by them.
A Freirean territory, using dialogue and content led by them.

argues that dialogue in math thing mathematics is provided by Benn, who dependency and isolation, and teaching with adults is essential to overcome or writing. This suggests, imp that this can take the form of ralking, reading, inguishable from conts, implicitly, that teaching through dialogue is indis-

For her, tradirional mous formative assessment. ${ }^{30}$

"banking education", in mematics teaching epitomizes Freire's concept of knowledge taken as needs to acknowledge the and fixed. Instead, she argues that mathematics empowered to create their vocial values it embodies, that learners should be culum should be concer own knowledge and that the mathematics currimathematical problems and with the generation and solution of real-life fine line of managing learnin questions by learners. Teachers must "walk the 
sensitively offering challenges to develop a deeper conceptualization of ematics".

Finally, in the first group, we find an argument that sees the dialogue at the z of democratic adult learning processes as a vital element of living in risk Y. Jansen and Van der Veen (1996) present a critique of post-modern 7, arguing that under conditions of modernity people are freed from tional social and ideological bonds but subjected to the anonymous hardizing rationalities of the state and the market. ${ }^{3 t}$

individuals are expected to take responsibility for their own lives, making ewn decisions, in contexts in which all sources of information are potencially table. The paper sees adult education as having a valuable potential function a btoker in problem-solving networks, raising issues of values, contracts atreen educators and learners, and new approaches to professionalism -monstrating both distance and involvement. It calls for reframing experiential eaming, in which expert knowledge and learners' experiences are subjected to firical and constructive group examination, through dialogue in which both nve equal status.

Adult education in this light will stick closer to the daily hopes and worries If learners, and be more prepared to further dialogue between conflicting aperiences, interests and ideological images. 'Teachers' roles will be to stimulate flection in a Socratic way, by raising awareness of the crucial questions to ask zstead of pretending to know the answers. This echo of Benn's view of the eguivocal certainty of traditional mathematics education demonstrates the imilarity of this view with Freire's perspective; in both cases the very broad nitw taken of adult education within societies undergoing radical change offers statively undefined guidance about the specific role of the teacher in this sination.

\section{Dialogue as A Useful Way for Specific Teaching and Learning Objectives}

This indistinct picture is perhaps clarified by the views of commentators on dialogue in the second group, who focus on three specific functions for the dialogic approach to teaching and learning. These in turn see dialogue as the 
means for teachers and learners jointly to research problems of understanding and to develop new knowledge and critiques of existing knowledge; as the joint evaluation of performance; and as the means by which teachers can gain understanding of learners' previous experience, so as to use this understanding for planning and differentiation. Seeing teaching and learning processes as research is perhaps a familiar idea in the context of higher education, though apparently 'a relatively low proportion of academics read the research journals on teaching their subject'. 32

For example, Ivanic suggests that the reachers' quest to find out the nature of a problem in understanding either literary conventions or the rules of conventional punctuation should be seen as a research project. This cannot be undertaken without the full participation of the learner, not just as research subject, but as researcher too, through dialogue. ${ }^{33}$

In the context of teaching writing, Ivanic argues that teachets should treat learner-writers as authorities, and that helping learners write what they mean necessitates talking, as a way of "researching" the content and literary conventions the learner wants to use. Dialogue therefore facilitates cooperative formative and diagnostic assessment of strengths, weaknesses, and barriers to learning and this is integral to teaching and learning. Most student and tutor pairs or groups talk a lot about the feelings and difficulties involved in writing. This sort of language awareness is being more and more widely recognized as an essential component of learning. What is different... is to recognize these insights as 'research findings' as 'knowledge'. ${ }^{34}$

Ivanic's later publication (1996) argues that non-standard punctuation is often based on perfectly logical thinking, and that standard punctuation is not in itself inherently logical. It is therefore crucial for teaches to discuss the thinking behind their mistakes with learners in order to help them understand standard punctuation. ${ }^{35}$ An instructive example of dialogue as formative assessment suggests that Introspection about strategies (for achieving the correct use of punctuation) is a useful teaching method in itself. Learners are thinking about meaning - they are logical even if they are mistaken.'

A similar view is proposed by Fowler and Mace (2005), who promote the idea of reaching and learning as research through joint mutual investigation 
nd teacher. They argue for the particular relevance of this cadult literacy, and their view supports not only Freire's account " $5^{\prime \prime}$, cognitive models of learning, in which the content is given but 's orientation to it is being investigated for learning purposes ( $i e$, Esormative assessment). ${ }^{36}$

The research model promoted is ethnographic, requiring a range of data diffetent sources and of different types, and a "grounded" research (Glaser and Strauss, 1967), in which findings 'emerge' gradually daca. It argues that this type research can deliver 'empowerment' to well as being a framework for improving literacy skills. ${ }^{37}$

Three papers focusing on the teaching and learning of writing argue with 2-is a al.'s (2004) review of research and practice finds that talking about wringsupports effective learning, and for the importance of learners expanding feir understanding of process aspects of writing, such as planning and revision, ead in which they can re-examine assumptions they might hold which may Stock learning, such as the idea that writing is either right or wrong. ${ }^{38}$ Similarly, mo American commentators argue that in the context of the learning of writing, trs cssential to enable learners to make explicit unarticulated ideas and concepts bout how people write, ${ }^{31}$ and to be involved in a process of 'co-constructing Ifpresentacions of their assumptions about the writing process: ${ }^{40}$ Russell found tat many students didn't understand that reading had any connection with -riting, and observed that while many teachers of writing for adult literacy Earners encourage their students to focus on content rather than form, most students want above all to avoid making 'mistakes', and that it is very hard to convince students that mistakes do not matter as part of learning. 'Teachers and learners appear to be speaking two different languages, perhaps different dralects of the language of writing instruction: 4 !

Dialogue is also a medium for collective assessment of a performance. Moss (1995) provides a detalled exploration of the role of the learner as w writer using the teacher as editor, in language experience learning situations. ${ }^{42}$ The paper shows how feedback that edits individual students' own words is 
problematic both for creative writing and the pursuit of the 'correct' use English. However, the process of negotiation between a teacher and learner which aims to facilitate the production of a finished and 'correct' but also authentic piece of work (central to formative assessment, and similar to the process of assessing a dramatic or musical performance), can be a powerful means of supporting future learning, confidence, and motivation. Condellit and Roberts et al. ${ }^{\text {h }}$ make similar points in relation to ESOL learners. They point out that the most significant mode of learning for ESOL learners is through group interaction.

In adult literacy education, Mace argues that dialogue between teacher and learner enables the teacher to understand as fully as possible the nature of the learner's previous experience of schooling and assessment. She uses extended quotations from adult literacy students to show the importance of schooling for their levels of motivation for engagement in formal learning, and in forming their attitudes and ideas about assessment, and their perceptions of success. She implicitly recognizes the notion of 'assessment careers' proposed by Ecclestone and Pryor. She argues that teachers have to understand the particular ways this experience impacts on learning as adults in order to find effective strategies for individuals and the group. Again, this view of dialogue corresponds closely with ideas about diagnostic assessment of a very broad range of needs, experiences and starting points. ${ }^{45}$

For Reder, it is absolutely essential that teachers and programs of learning engage with learners' culture and backgrounds. He cites educational and anthropological research which contradicts theories of learning suggesting that learners simply lack skills which they need to acquire: rather, whatever their age, experiences and cultural background, learners arrive already familiar with a range of literacy practices associated with their particular family and social environment, practices that Reder describes as 'context-specific'. Failure to recognize this has led programs to make erroneous assumptions about the home lives of students from poor, minority or immigrant families as being 'deficient' environments for supporting literacy development, resulting in a mismatch between what learners are familiar with in relation to literacy practices, and what the program teaches. ${ }^{4 h}$ 
On the basis of this wide-ranging survey of research, Reder argues for the pportance of what he calls 'practice-engagement theory', which proposes - teachers and programs must understand how literacy practices develop tasugh collaborative activity, that 'participation structures' are contexts for incy development, that social meanings shape literacy development, and - lireracy develops primarily chrough becoming conscious of and extending =ing practices, rather than through the learning of 'new' ones. In particular, merice engagement theory provides accounts for how fluency in literacy pertices can be developed without formal instruction. It follows from this - formal instruction needs firstly to be aligned as far as possible to the pecific literacy practices that individual learners' are familiar with already, wa secondly, to try to build learning on these practice-specific contexts rather tas separately from them. Each of these requires teachers to investigate the pecific practices and contexts that their learners are already familiar with, the Frilc of which may be quite different in each case. ${ }^{47}$

One group of commentators, supporting the importance of dialogue in ching and learning, point out that if a teacher is to initiate, support and trif from dialogue with learners, they will need complex communication skills. These papers consider in more detail what these skills are, and how teachers - ght be supported and trained to develop and maintain them.

Alexander, for example, argues that teacher training should be essentially Silogic in form, so as to exemplify and at the same time develop the necessary kills and dispositions. ${ }^{43}$ Beder reports that how teachers interact with adult veiceducation learners is an important factor in engagement, which is defined a his study as 'trying hard to learn'. His report says less about the nature of trese interactions than about the diffetence made by their frequency, with mplications for teachers with larger groups. 49

Belfiore and Folinsbee, in an ethnographic study of adult learners in the workplace, show how a manager delivering formal training on new qualicy control systems needs to allow employees to voice criticisms of the present quality regime in practice, in order to gain credibility and engage the employees the formal aspects of the course. Teachers and trainers in the workplace, whether professionals delivering formal programs or peers supporting learning 
on the job, need to exemplify effective communicative practices themselves. The paper thus argues for the integration of training with work practice, and demonstrates the strong link berween the organizational style and culture of the workplace, and effective learning at work. ${ }^{50}$

Merton reports on a study of basic skills provision among young adults that teachers' language should be 'easy to understand and avoid long words' Choice of words and tone of voice seemed to influence how the young people performed under pressure, and their motivation to continue their learning." Ward and Edwards report that adult literacy and numeracy learners' prefer reachers who "listen' ',2, Gardener also highlights the importance of listening to learners in the context of teaching writing, in order to ensure that judgments of value and of approptiateness (of tone, or of grammar) are arrived at mutually rather than imposed. ${ }^{39}$

This issue is at the heart of the discussion by Zuss, who, from a Freirean perspective:

"The privileging of certain modes of discourse and organization of knowledge involves institutionalized norms of rationality, meaning making, and literate interaction - modes that, unevenly at best, include as well as exclude salient varieties of cultural expression...., these values are inculcated, however implicitly and indirectly, by well-intencioned teachers and administrators, through privileged forms of language and linguistic interaction". . $^{4}$

In addressing this problem, teaching and learning needs to be secn from a social constructivist perspective, in order to avoid psychological or social reductionism:

"Ir is vital to examine the experiential and cognitive resources individual from diverse ethnic and sub cultural origins bring to the cross-cultural classroom Echnographic description of classrooms alone, however, while essential, is not always sufficient to explain the uneven levels of literacy, or cultural capical wichin and between first and second languages and their complex interpla within matrices of power, culture, and value"."55

From this perspective and in discussing the education of sccond languag= students, Zuss develops a critique of 'process approaches' to the teaching andlearning of language and literacy, which he argues:

'emphasize 'free writing', non-directive teaching, and the use of journals fí personal writing experience (and) are intended to permit self-expression and the 
generation of stodent-centered cexts in non-authocitariat coutexts. in actual classroom practice, however, the process approach cao sene to suppress the development of voóce. Particularly in cross-cultural sertings, emphasis on process over produxt, or 'organism' over mechanism, while generative of writing, can disregard the salient culnual thoices members of discourse conmunicics are tikely to use in self-representaricon and expression", ss

'Talk is work in the language classroom', as one group of commencators has said." Zuss's analysis serves as a reninder of lows difficult this work can be: the emphasis on dialogue in teaching and learning has highly complex and demanding implications for boch veachers and students in terms $\alpha$ addressing issues of discourse, power, identiry, ardi agency, ss well as leaming, boch in the classtoon setting and in the wider work.

Finally in this section, it is important ro highlighr the position of commentators wbo atgue that one of the pedagogical advantages of a dialogic approach is the expression, clarifcarion and explonation of conflicting belicfs or vicespoincs. Nonesuch quoces a small scale rescarch study suggesting that the extemalisation and expression of resistance to aspects of the karning siruation can be a critical stage in negociacing a developmental process with the learner tesulting in more commitment to learning rather than less. ${ }^{*}$ Swan, in a comparative study of differenc podagogicat approaches in mathemacics, argues that it is ofven through the provocstion of 'cogritive oonflicts' that the most effective learning cakes place. He reporcs on three experiments in which 'expository teaching' spprcaches were compared with 'conflict ard discussion', He finds that when lentners existing coxacepeual approachs vere identificd and subjected to conflict comparisca, markedily better sceess for uttainment and understanding were schieved, than with moec tradicional modes of expository ceaching. He suggests that this greater effoctiveness is due to 'the identification of and focas on specific concepcuat obstacles, the emphasis on oral rathet than textual explanation, the increased level of challenge offered, the intensity of discussion and involvement generated, and the valuing of incuicive methods and explicit recognition of conceptual obstacles', each of which imply the centrality of diabogue in the process of leaming. 


\section{Closing}

Dialogue beeween ceachers and learners is seen by different commentators either as a central clement of all teaching and learning, or alternatively as important in achieving a range of specific pedagogical objectives. For the first group, social interaction is the key mechanism through which learning takes place, and teaching is the creacion of opportunities for learning through the management of interaction. It enables learners to practice and acquire the languages of different communities of practice, to 'own' the learning process and what is learnt. Through it teachers can engage with learners' previous experiences, and thas their beliefs and feelings abour learning. For the second group, dialogue is the means by which teachers get information to support planning and differentiation, through which learning can be a joint process of research between teacher and learner, through which teachers can find out ahour learners misapprehensions and misconceptions, and through which teachers can understand the knowledge, skills and practices that leamers already have. Both perspectives put a premium on the need for teachers to be able to use the highest and broadest levels of communicative skills.

\section{Endnotes}

${ }^{1}$ Bambang Sugeng, "Strategi Belajar Bahasa Inggrís Sebagai Bahasa Asing Kaitannya dengan Faktor-Faktor Demografik pada Pembelajar Dewasa", DIKSI, Vol II No, 1, Jan 2004.

"M. Knowles, "Andragogy: An emerging technology for adult learning", in Boundaries of Adult Leaming, Ed Edwards R. Hanson A, and Raggatt P, Open University 1996.

3. Hostler, Student autonomy in Aduit classes, Manchester Monologue (University of Manchester Centre for Adult and Higher Education, 1986).

"R. Wiltiams (1993), "Border Country - Raymond Williams in Adult Education", in J, Mcilroy and S. Westwood (Ed.). NIACE, Leicester, and Fieldhouse, R. and associates (1996), A History of Modem British Adult Educotion, NIACE.

${ }^{5} 0$. Boud $(2000)$ : Sustainable assessment: rethinking assessment for the learning society, Studies in Continuing Education, 22(2) 151-167 and R Ivanic (1996): Linguistics and the Logic of Non-standard Punctuation, in Learning about Punctuation, ed N Hall and A Robinson, Multilingual Matters, pp148-169

D. D. Boud (2000): Sustainable assessment: rethinking assessment for the learning society, Studies in Continuing Education, 22(2) 151-167

'V. MoGivney (1996): Academic Support, Chapter 10 of Staying or leaving the course: non-completion and retention of mature students in FHE, Leicester: NLACE 1996 and 
Eldred J, Ward J, Snowdon X, Dutton Y (2005): Catching Confidence - the natuse and rote of confidence ways of developing and recording changes in the learning context, Leicester: NLACE 2005

"S. McNair, "Learning Autonomy in a Changing World", in Boundanies of Adult Leaming. (Ed.) Edwards et al (Routledge, 1996).

* K. Tusting and Barton D (2003): Models of adult leaming - a titerature review, London; NRDC, Institute of Education, 2003; republished Leicester: NIACE 2006

${ }^{10}$ L.S. Vygotsky (1962), Thought and Language, MIT Press.

${ }^{11}$ R. Alexander, Towards Dialogic Teaching - Rethinking Classroom Tolk (Dlalogos, 2004).

12. B. Marr (2000): Talking volumes: enhancing talk, language and conceptual development in adult mathematics and numerscy classes, Literacy and Numeracy Studies: an international joumal in the education and training of adults, 10 (182), pp 55-70, also reprinted in Kelly S, Johnston B, and Yasukawa K, (eds): The Adult Numeracy Handbook - reframing adult numeracy in Australia, New South Wales Adult Literacy and Numeracy Australian Research Consortium 2003, pp 275-286

II Ibid.

*Ibid.

${ }^{15} \mathrm{M}$. Swan (2006): Collaborative learning in mathematics - a challenge to our beliefs and practices, London and Leicester: NRDC and NIACE

to $\mathrm{M}$. Absolum (2006): Clarity in the classtoom: using formative assessment, Auckland: Hodder Education 2006

17. Ibid.

tas Ibid.

10 D. Barton, Ivanic R, Appteby Y, Hodge R, Tusting K et al. (2004): Adult Leamers' Lives project: setting the scene, London: NROC Progress Report, April 2004 and Ivanic R, Appleby $Y$, Hodge R, Tusting K, and Barton D (2006): Linking learning and everyday life: a social perspective on adult language, literacy and numeracy classes, London: NROC Research Report April 2006

${ }^{n}$ D. Barton, Appleby Y, Hodge R, Tusting K, Ivaric R (2006): Relating adults' lives and learning: participation and engagement in different settings, London, NRDC Research Report, April 2006

II D. Barton, Ivanic R, Appleby Y, Hodge R, Tusting K et of. (2004): Adult Leamers' Lives project: setting the scene, London: NRDC Progress Report, April 2004

27. 0 . Barton and Papen U, Linking biteracy and numeracy programmes in developing countries and the UK (London: NRDC Research Report, September 2005).

${ }^{23} \mathrm{~K}$. Nonesuch (2006): Changing the way we teach Math - a manual for teaching basic math to adults, available at www.nald.ca/ibrary/leaming/mathman/mathman.pdf, accessed 23-03-07

24 L. Ginsburg and Gat I (1996): Instructional strategies for teaching adult numeracy skills, National Centre on Adult Literacy Technical Report TR96-02. Philadelphia: University of Pennsylvania, available at www.literacyonline.org/products/ncal/pdf/TR9602.pdf, accessed 23-03-07. 
As M. Swan, Collaborotive leaming in mothematics - a chollenge to our beliefs and practices (London and Leicester: NRDC and NIACE, 2006).

* R. Ivanic and Tseng ML. Understonding the relationships between learming and teaching: An anolysis of the contribution of applied linguistics (London: NRDC Research Report 2005).

"A. Belzer "It's not like normal school"; The role of prior learning contexts in Adult Learning", Adult Education Quarteriy Vol 55 No 1 2004, pp. 41-59

${ }^{27}$ M. Baxter, Leddy E, Richards L, Tomlin A, Wresniwiro I, Coben D, Measurement wasn't taught when they buit the pyramids - was it? The teaching and leaming of common measures in aduit numeracy (London: NRDC Research Report. April 2006).

Do P. Freire, The Pedogogy of the Oppressed (Sheed and Ward, 1972), chapters 2 and 3.

m. Benn, "Reading, writing and talking about mathematics, in D Coben, ed Adult Learning Maths" - a Research Forum, Proceedings of AL.M-3, the Third International Conference, Brighton UK, pp24-29, London Goldsmiths College/ALM and Benn R (1997b): "Adults count too". NIACE 1997.

"Jansen and Van der Veen, "Adult Education in the tight of risk society", in The Leaming Society, Ed Raggatt et al. (Routledge, 1996).

31 D. Laurillard, Rethinking University Teoching (Routledge, 1997).

3. R. Ivanic, "Linguistics and the Logic of Non-standard Punctuation", in N. Hall and A. Robinson (Ed.). Leaming about Punctuation (Multilingual Matters, 1996), pp. 148-169.

3- R. Ivanic and Simpson J. 1988: Clearing away the debris: Learning and researching academic writing. RaPAL bulletin No 6 Summer 1988, reprinted in Insights from research and practice, ed M Hernington and A Kendall, Leicester: NLACE 2005, pp246-250

* R. Ivanic (1996): Linguistics and the Logic of Non-standard Punctuation, in Learming about Punctuation, ed N Hall and A Robinson, Multilingual Matters, pp. 148-169.

"E. Fowler and Mace J (2005); Outside the Classroom, researching literacy with adult learners, Chapter 4, Leicester: NIACE 2005.

97. B. Glaser and A. Strauss (1967), Grounded Theory: Strotegies for Qualitative Research, Sociology Press.

38 S. Kelly, Soundranayagram L, GriefS (2004): Teaching and learning writing: a review of research and practice, London: NRDC Research Report, June 2004.

"M. Russell (1999); The assumptions we make: How leamers and teachers understand writing. Focus on Basics, 3(D), 20-23.

20 M. Gillespie (2001): Research in writing; implications for adult literacy education. in $J$ Comings, B Garner, and C Smith (eds), NCSALL annual review of adult learning and literacy, 2, 63-110. San Francisco: Jossey Bass 2001.

4 M. Russell (1999): The assumptions we make: How learners and teachers understand writing. Focus on Basics, 3(D), 20-23.

Q W. Moss (1995): Controlling or Empowering? Writing Through a Scribe in Adult Basic Education, in Literacy, Language and Community Publishing; Essays in Adult Education, ed Mace J, Multilinguat Matters. 
L. Condelli (2002): Effective instruction for Adult ESL students: findings from the what Works' Study, accessed 31-12-06 from www.nrdc.org.uk/uploads/documents/ doc_54.pdf

- C. Roberts, Baynham M, Shrubshall P, Barton D, Chopra P, Cooke M, Hodge R, Pitt K. Schellekens P, Wallace C, Whitfield S (2004): English for Speakers of Other Languages (ESOL) - case studies of provision, learners' needs and resources, London: NRDC Research Feport, August 2004.

45 J. Mace (1979): Working with Words, Literacy Beyond SchooL, London: Writers and Feaders Publishing Co-operative (especially chapter 4, Measuring the Journey).

*s. Reder (1994): Practice engagement theory - a sociocultural approach to literacy across languages and cultures, in Literacy across Languages and Cultures, ed Ferdman B. Weber R, and Ramirez R. Albany: State University of New York Press, pp. 33-74.

$\checkmark 7$ Ibid.

* R. Alexander (2004): Towards dialogic teaching - rethinking classroom talk, Dialogos 2004.

4F. Beder (2005): Research on factors that shape engagement, Focus on Basics, Vol T Issue D.

M. E. Belfiore and Folinsbee S (2004): Workplace Learming and Literacies in Practice, in Reading Work: Literacies in the New Workplace, ed ME Belfiore, TA Defoe, $S$ Folinsbee, J Hunter, N Jackson, Lawrence Eribaum Associates.

\% B. Merton (2001): Encouraging interest, Adults learning 12(5) 7-10.

52 J. Ward and Edwards J (2002): Learming Journeys: learners' voices, LSDA 2002.

sS. Gardener (1985): Conversations with Strangers, ALBSU/Write First Time 1985.

34 M. Zuss (1994): in Literacy across Languages and Cultures, ed Ferdrnan B, Weber R. and Ramirez R. Albany: State University of New York Press, pp. 239-272.

M Ibid.

* Ibid.

I C. Roberts, Baynham M, Shrubshall P, Barton D, Chopra P, Cooke M, Hodge R, Pitt K, Schellekens P, Wallace C, Whitfield S (2004): English for Speakers of Other Languages (ESOL) - case studies of provision, leamers' needs and resources, London: NRDC Research Report, August 2004.

* $\mathrm{K}$. Nonesuch (2006): Changing the way we teach Math-a manuat for teaching basic math to adults, available at www.nald.ca/tibrary/learning/mathman/mathman.pdf, accessed 23-03-07.

* M. Swan (2006): Collaborative learning in mathematics - a challenge to our beliefs and practices, London and Leicester: NRDC and NIACE.

\section{References}

Absolum M. 2006. Clarity in the classroom: using formative assessment. Auckland: Hodder Education. 
Alexander R. 2004. Towards dialogic teaching - rethinking classroom talk. Dialogos: Argyris, C. and D. Schön (1974), Theory in Practice: Increasing Professional Effectiveness, Jossey Bass, San Francisco.

Barton D and Papen U. 2005. Linking biteracy and numeracy programmes in developing countries and the UK, London: NRDC Research Report, September 2005.

Barton D, Appleby Y, Hodge R, Tusting K, Ivanic R. 2006. Relating odults' lives and learning: participation and engagement in different settings. London, NRDC Research Report, April 2006.

Barton D, Ivanic R, Appleby Y, Hodge R, Tusting K et al. (2004): Adult Learners Lives project: setting the scene, London: NRDC Progress Report, Aprih 2004. Baxter M, Leddy E, Richards L, Tomtin A, Wresniwiro T, Coben D (2006): Measurement wasn't taught when they built the pyramids - was it? The teaching and learning of common measures in adult numeracy, London: NRDC Research Report, April 2006.

Beder H. 2005. Research on factors that shape engagement, Focus on Basics, Vol 7 Issue D.

Belfiore ME and Folinsbee S. 2004. "Workplace Leaming and Literacies in Practice", in ME Belfiore, et a! (Ed). Reading Work: Literacies in the New Workplace. Lawrence Erlbaum Associates.

Belzer A (2004): "It's not like normal school": The role of prior learning contexts in Adult Leaming. Adult Education Quarterly Vol 55 No 12004.

Benn R (1997a): Reading, writing and talking about mathematics, in D Coben, ed Adult Leaming Maths - a Research forum, Proceedings of ALM-3, the Third International Conference, Brighton UK, London Goldsmiths College/ALM Benn R. 1997b. Adults count too, NIACE 1997.

Boud D. 2000. Sustainable assessment: rethinking assessment for the learning society. Studies in Continuing Education.

Condelli L 2002. "Effective instruction for Adult ESL students: findings from the 'What Works' Study", accessed 31-12-06 from www.nrdc.org.uk/uploads/ documents/doc_54.pdf

Derrick, J. and K. Ecclestone. 2008. "English language Literature Review", in Teaching, Learning and Assessment for Adults: Improving Foundation Skills, OECD Publishing. 
Ecriestone, K. and J. Pryor, 2003. "'Leaming Careers' or 'Assessment Careers'? The Impact of Assessment Systems on Learning", British Educational Research Joumal, Vot. 29 (4).

Elised J, Ward J, Snowdon K, Dutton Y. 2005. Catching Confidence - the nature and role of confidence ways of developing and recording changes in the learning context, Leicester: NIACE 2005.

Feldhouse, R. and associates. 1996. A History of Modern British Adult Education, NIACE.

Fowler E and Mace J. 2005. Outside the Clossroom, researching literacy with aduit learners, Chapter 4. Leicester: NIACE 2005.

Ficire, P. 1972. The Pedagogy of the Oppressed. Sheed and Ward.

Gardener S. 1985. Conversations with Strangers, ALBSU/Write First Time 1985.

Gllespie M. 2001. "Research in writing; implications for adult literacy education", in J Comings, B Garner, and C Smith (Ed.), NCSALL annual review of adult leaming and literacy, 2, 63-110. San Francisco: Jossey Bass 2001.

Ginsburg L and Gal I (1996): Instructional strategies for teaching adult numeracy skills, National Centre on Adult Literacy Technical Report TR96-02. Philadelphia: University of Pennsylvania, available at www.literacyontine.org/ products/ncal/pdf/TR9602.pdf.

Glaser, B. and A. Strauss. 1967. Grounded Theory: Strategies for Qualitative Research, Sociology Press.

Hostler 3. 1986. Student autonomy in Adult classes, Manchester Monologue, University of Manchester Centre for Adult and Higher Education 1986.

Ivanic R. 1996. "Linguístics and the Logic of Non-standard Punctuation", in N Hall and A Rabinson (Ed.). Leaming obout Punctuation. Multilingual Matters Ivanic R, Appleby Y, Hodge R, Tusting K, and Barton D. 2006. Linking learning and everyday life: a social perspective on adult language, literacy and numeracy classes, London: NRDC Research Report, April 2006.

Ivanic R, Tseng ML (2005): Understanding the relationships between learning and teaching: An analysis of the contribution of applied linguistics, London: NRDC Research Report 2005.

Jansen and Van der Veen. 1996. "Adult Education in the light of risk society", in Raggatt et al. (Ed.). The Leaming Society. Routledge. 
Kelly S, Soundranayagram L, Grief S. 2004. Teaching and learning writing: a revier of research and practice. London: NRDC Research Report, June 2004.

Knowles, M. 1983. "Andragogy: An emerging technology for adult learning", in Edwards R, Hanson A, and Raggatt P. (Ed.). Boundaries of Adult Leaming. Open University 1996.

Laurillard, D. 1997. Rethinking University Teaching. Routledge.

Mace, J. 1979. Working with Words, literacy beyond school. London: Writers and Readers Publishing Co-operative (especially chapter 4, Measuring the Journey). Marr, B. 2000. Talking volumes: enhancing talk, language and conceptual. development in adult mathematics and numeracy classes, Literacy and Numeracy Studies: an international journal in the education and training of adults, 10 (182), also reprinted in Kelly S, Johnston B, and Yasukawa K. (eds): The Adult Numeracy Handbook - reframing adult numeracy in Australia, New South Wales Adult Literacy and Numeracy Australian Research Consortium 2003

McGivney, V. 1996. Academic Support, Chapter 10 of Staying or leaving the course: non-completion and retention of mature students in FHE, Leicester: NIACE 1996

McNair, S. 1996. "Learning autonomy in a changing world", in Edwards et at. (Ed.). Boundaries of Adult Learning. Routledge.

Merton, B. 2001. Encouraging interest, Aduits learning.

Moss, W. 1995. Controlling or Empowering? Writing Through a Scribe in Adult Basic Education, in Literacy, Language and Community Publishing: Essays in Adult Education, ed Mace J, Multilingual Matters.

Nonesuch, K. 2006. Changing the way we teach Math - a manual for teaching basic math to adults, available at www.nald.ca/library/learning/mathman/ mathman.pdf

Reder, S. 1994. Practice engagement theory - a sociocultural approach to literacy across languages and cultures, in Literacy across Languages and Cultures, ed Ferdman B, Weber R, and Ramirez R. Albany: State University of New York Press.

Roberts C, Baynham M, Shrubshall P, Barton D, Chopra P, Cooke M, Hodge R, Pitt K, Schellekens P, Wallace C, Whitfield S (2004): English for Speakers of Other 
Languages (ESOL) - case studies of provision, learners' needs and resources, London: NRDC Research Report, August 2004.

Pussell, M. 1999. The assumptions we make: How leamers and teachers understand writing. Focus on Basics, 3(D)

Sadler, R. 1989. "Formative Assessment and the Design of Instructional Systems", Instructional Science, Vol. 18.

Swain, J (2005): Changes to Adult Learners' Identities through Leaming Numeracy, Literacy and Numeracy Studies, Vol 14 No 1.

Swain J, Griffiths G, Stone R (2006): Integrating formative/diagnostic assessment techniques into teachers' routine practice in adult numeracy, Research and Practice in Adult Literacy, Vol 59 Spring 2006.

Swan, M (2006): Collaborative learning in mathematics - a challenge to our beliefs and practices, London and Leicester: NRDC and NIACE.

Tusting K and Barton D. 2003. Models of adult learning - a literature review, London: NRDC, Institute of Education, 2003; republished Leicester: NIACE 2006.

Vygotsky, L.S. 1962. Thought and Language, MIT Press.

Ward J and Edwards J. 2002. Learning Journeys: leamers' voices, LSDA 2002 Williams, R. 1993. "Border Country - Raymond Williams in Adult Education", in J. McIlroy and S. Westwood (Ed.), NIACE, Leicester.

Zuss M. 1994. in Literacy across Languages and Cultures, ed Ferdman B, Weber R, and Ramirez R. Albany: State University of New York Press. 